\title{
Effect of Compensation and Benefit to Employee Engagement through Organisation Brand in Indonesia's Startup Company
}

\author{
Astri Utami Indriyani \\ Dr. Ir. Ignatius Heruwasto* \\ Universitas Indonesia
}

\begin{abstract}
Startup business in Indonesia has become a popular way to start the business. Startup is as well a promised business in the field of infestation and pay/salary. Does pay and facility is suit well with their job description and makes the engage to company? This paper tests the hypothesis that compensation and benefit have effect on employee engagement with organization brand in between. Result shows that organization brand failed to be mediating variable just because only compensation that has effect, which is on organization brand and employee engagement. Which engagement is affected as well by compensation.
\end{abstract}

\begin{abstract}
ABSTRAK
Perusahaan startup (startup company) di Indonesia telah menjadi cara yang populer untuk beberapa orang memulai bisnisnya. Startup juga merupakan bisnis yang menjanjikan dari segi investasi dan gaji. Gaji dan fasilitas yang diberikan kepada karyawan apakah sudah sesuai dengan bobot kerja mereka dan mendorong mereka terikat dengan perusahaan? Penelitian ini menguji pengaruh compensation dan benefit terhadap employee engagement dengan adanya organisation brand di antaranya. Hasil menunjukkan bahwa organisation brand tidak menjadi mediator karena hanya compensation yang berpengaruh terhadap employee engagement dan dipengaruhi pula oleh organisation brand.
\end{abstract}

Keywords: Startup, organisation brand, employee engagement, compensation, benefit. 


\section{Astri Utami Indriyani \\ Ignatius Heruwasto}

\section{INTRODUCTION}

Few years now in Indonesia, there are some distraction by some online application that provide any services needed by the citizen. Such as riding, sending packages, food, even home cleaning and beauty services. This kind of disruption on transportation business then known as online ojek. Few player in this business are Gojek from Indonesia, Uber from US or Grab from Malaysia. The business they run named start up business. For year 2016, Tech In Asia published an article about startup in Indonesia and this article discuss about:

1. The government have huge attention about startup. They made some e-commerce roadmap about universal service obligation (USO) and incubator program and tax.

2. Funding from investor to startup company rising.

3. There is development in e-commerce supporting business like payment methods and expedition services.

4. E-commerce from country outside Indonesia expand their business here.

5. Some e-commerce played in specific market field.

6. Indonesia got a lot of discount day.

In 2016, there are 88 startup that given funding from the investor. Three highest funding come for Gojek in amount of USD 550 million, Tokopedia got USD 147 million, and MatahariMall.com with funding USD 100 million. Some investor to Indonesia's startup business including East Venturem 500 Startups, and Prasetia. Another source which is Kumparan.com-a website of any information-shows the fact about development of startup business in Indonesia. From the ability of buying from customer, from transaction amount of Fintech, and prediction of information technology buying, all shows the risen of the amount. It means that startup business in Indonesia is a promising way of the success.

Not only the success one, startup is also facing some failure. In Indonesia, there are nine startups which left by the key person, either the founder or the board. Another startups are bankrupt and decided not to continue its operational business. Based on information from maxmanroe.com about the reason employee left their company, one of the reason is pay. The pay they got is not similar with job they done. Meanwhile, almost everything needed in life supported by money. Talking about salary, one of known startup in Indonesia, named 2 Gojek, have their employee salary amount on Rp 6.000.000,00 until Rp 19.500.000,00, Qerja.com told. This is quite a huge amount of salary for a new beginning company. Ain't this amount of salary is enough? Too much money goes from employee possibly another reason of a startup to forcefully stop the business.

Whether startup that fail or success, each of them have unique identity. Gojek is well known with a tagline "An Ojek for Every Needs", Tokopedia have a common question "Sudah cek Tokopedia belum?" which means everything you need is in Tokopedia. All you need is check in there. The identity they explain to consumer is about organization choice of strategy and the expectation about (Abratt \& Kleyn, 2011). This kind of identity is an aspect of corporate brand, expression and identity of an organization (Abratt \& Kleyn, 2011). To explain the internalization of brand to themselves, organization needs some characteristics. One of the characteristics is a reward for everyone who have commitment to internalized the brand of organization (Armstrong, 2000; Mullich, 2003; cited by Boyd \& Sutherland, 2006). Rewards in 
financial forms is most anticipated factor by employee and become a most successful factor (Herman \& Gionia, 2000; cited by Boyd \& Sutherland, 2006).

On the process of employee live the brand, they got clearer direction about the job they do and they also believe that there is an effort of the company to satisfy consumer and employee, that makes employee have commitmen towards company (Punjaisri, Wilson, Ecanschitzky, 2009). As employee comes closer to the company, employee engagement will appear. Employee engagement based on theory by Right Management (2000, cited bu Ahmad, 2014) is when every person in the organization understanding and being committed to the success of the business strategy and that this goes more than just simple job satisfaction and incorporates aspects of commitment, pride and advocacy about the organization's products and brand. As a consideration of those topics mentioned above, so I decide to write down a research.

The question we need to answer are: 1) Is compensation have effect on organization brand?; 2) Is benefit have effect on organization brand?; 3) Is compensation have effect on employee engagement?; 4) Is benefit have effect on employee engagement?; 5) is organization brand have effect on employee engagement?

\section{LITERATURE REVIEW}

Rothwell \& Kazanas (2003) define compensation as a feedback received by employee in form of monetary and non-monetary. Compensation is direct and indirect. Direct compensation such as salary received every month and indirect compensation is a payment in form others than money. Martocchio (2015) said that compensation is an intrinsic and extrinsic reward received by employee after they done their work. While Milkovich (2014) said that compensation is a reward received by employee based on anything employee do at the moment they work. In an article written by Hwang \& Kleiner (2002), they mentioned the purpose of the compensation as to insure that the employees injured on the job are provided compensation in accordance with the Workers' Compensation Act and to provide consistent application of these rules and regulations. Further, the purpose is not only to provide swift and certain remedy to an injured employee, but also to insure a limited and determinate liability for the employer.

The other variable in this research is benefit. Rewards that given to the employee in different form than compensation (Murphy, 2010). Usually in term of pension, health insurance, day off, and any kind of allowances. Benefit can give another important role in reward strategies because it can improve the quality of self and job of employee.

Then we talk about organization brand, expressions and images of an organisation's identity (Abratt \& Klyen, 2011). Brand supposed to be visual, verbal, and behavior expression which is unique from corprate's business model. In order to implement 3 organization brand, there are five factors called 5C (Blumenthal, 2011). These are clarity, commitment, communications, culture, and compensation. Connected to previous theory, compensation in term of factor supporting the appearance of organization brand, compensation is given to the employee because employee give their focus in representing the brand by themselves. There are four 


\section{Astri Utami Indriyani \\ Ignatius Heruwasto}

factors in organization brand, brand identification, brand commitment, brand loyalty, and the last is brand performance.

All these theory will be seen its effect on a dependant variable called employee engagement. Kahn (1990, cited by Condos, 2016) defined employee engagement as harnessing of organization members' selves to their work roles, in engagement, people employ and express themselves physically, cognitively, and emotionally during role performance. Research by Du Plessis (2014) showed that engaged employee results in $95 \%$ higher assets, $68 \%$ higher sales, and $29 \%$ intended to retain at this current company. Anitha J (2013) defined seven factors that support the existence of employee engagement. Those seven factors are job environment, leadership, team, training and development, compensation, company rules, and workplace well being.

About the startup itself, usually involve technology, sometimes a small company that have hard technical problem and make money by inventing new technology (Graham, 2015). In article on maxmanroe.com, startup has some characteristics. Company establish less than three years, total employee less than 20 persons, revenue is less than USD 100.000 each year, still in development process, usually operating in technology, products is about digital application, and usually operating through some website. But those who called startup is not limited to characteristics mentioned above.

\section{METHODS}

To test the hypotheses I have conducted an empirical study and collecting 216 employees from different set of startup business in Indonesia. The model in this research is as mention below and we proposed five hypotheses consist of one dependent variable, two independent variable, and one mediating variable.

Table 1. Research Model

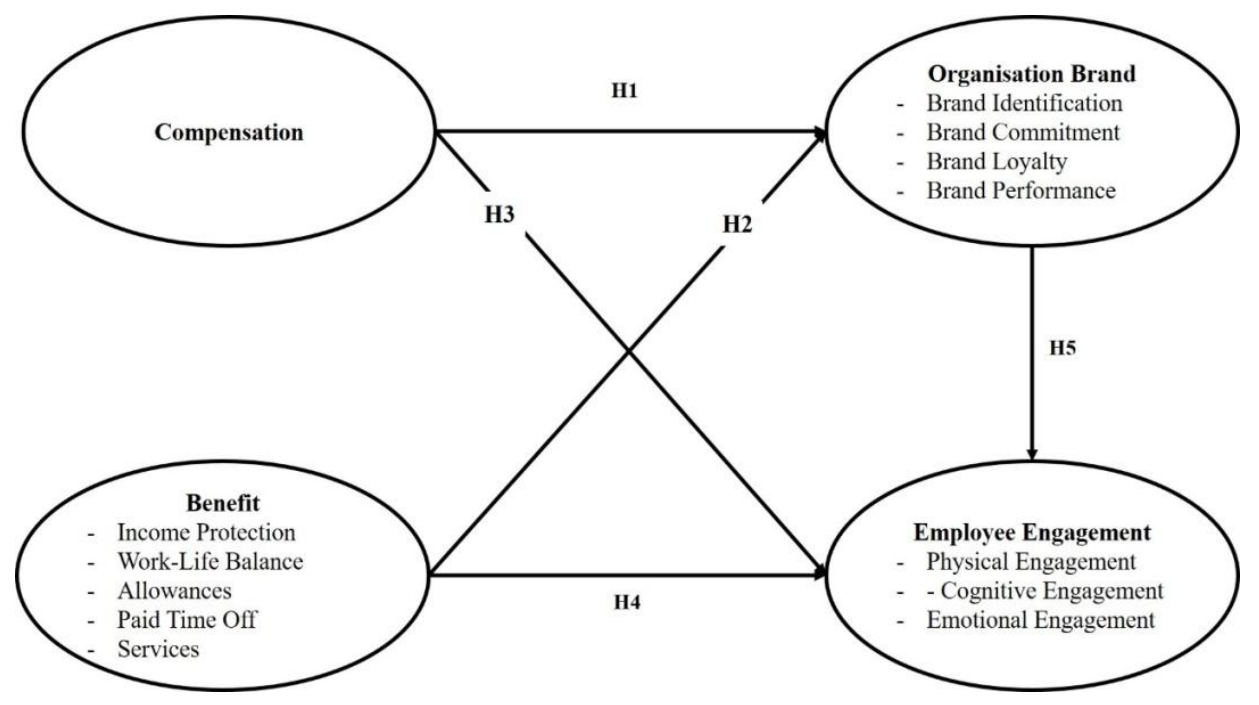


There are similar theories about organisation brand (or as well known as corporate brand). Abratt \& Kleyn (2011) defined organisation brand as expressions and images of an organisation's identity. Balmer \& Grat (2003) said corporate brand as sign of belonging, 4 tools to build company's image, and symbol of important values of the company. If employee is able to understand the brand of its company, therefore they will got clearer brief of job and believe that there is effort from company to satisfy its customer, employee will build their commitment towards company (Punjaisri, Wilson, Evanschitzky, 2009; Mitchell, 2002). In building organisation brand, there are five key factors as said by Blumenthal (2011), clarity, commitment, communications, culture, and compensation. If clarity is about how clear information in employee about the brand, communications is about how management communicate brand to employee, culture is about the way, therefore compensation is about feedback given to employee about what they do with the brand. Boyd \& Sutherland (2006) made a research about how employee internalised the brand of their current employer. Result shows that it correlated to compensation. So two first hypotheses we proposed are:

H1: Compensation has effect on organisation brand.

$\mathrm{H} 2$ : Benefit has effect on organisation brand.

Still talking about compensation and benefit, Anitha J (2013) mentioned compensation as one of the factor facilitating the existence of employee engagement. Maylett \& Nielsen (2012, cited by Abel 2013) believe that employee engagement will increase profit and decrease outcome if employee is satisfied. Abel (2013) as well said that engagement came from the feeling that they got perfect compensation about what they already did. Bender, Contacos-Sawyer, and Thomas (2013) believe that benefit to employee is a driver to increase employee engagement. The positioning of right beneft will impact not only to employee but also to their families. Comes from this believe, we propose another hypotheses, these are:

H3: Compensation has effect on employee engagement.

$\mathrm{H} 4$ : Benefit has effect on employee engagement.

On the others research did by Ahmad et al (2014) in a service company in Dera Ghazi Khan, they found a conclusion that there is positive correlation between brand and employee engagement. Research in Dera Ghazi Khan become basis on the making of correlation model between organisation brand and employee engagement. We believe that in Indonesia as well organisation brand have effect on employee engagement. Therefore the last hypotheses become:

H5: Organisation brand has effect on employee engagement.

When we illustrate the relationship of those four variables, we can see that organisation brand can be a mediating variable which mediating compensation and benefit to employee engagement. But it depends on the results. If relationship between compensation with organisation brand, organisation brand with employee engagement, and 


\section{Astri Utami Indriyani \\ Ignatius Heruwasto}

compensation with employee engagement all is found significant, than organisation brand will be partial mediator. Because without mediating variable, independent variable can still have effect on dependent variable. But on the other side, if compensation with organisation brand and organisation brand with employee engagement have effect but not with compensation with employee engagement, therefore organisation brand is a full mediator. Because compensation will have no effect unless organisation brand is there. Third condition is on those relationships, nothing is significantly have effect. Then it concluded that organisation brand is not a mediator. Same condition ges to benefit if benefit replace the position of compensation.

All these hypotheses tested in this research to startup business emerging in Indonesia. To answer the question of the research, we use the quantitative research method. Primary data collected from first hand respondent. The data that has been collected treated using SPSS 16.0 version. Questionnaire chosen by consideration as most easy to get research tools and respondents will easily answer as well. The research goes to everyone who work in startup business regardless their gender and duration of work. Through non-randon 5 sampling method which whoever can be a participant as long as they are work in startup business.

At the preparation stage, researcher needs to prepare the concept, the questionnaire, and the data collecting way. Questionnaire in this research originally from other research. Organisation brand questionnaire is an adaptation of Punjaisri et al (2009) with some transalation to fit into Indonesian language and understanding. While the questionnaire of employee engagement is the development of Kahn (1990). Scale in the questionnaire is Likert scale with 6 rate from 1 as Very Inappropriate to 6 as Very Appropriate. Researcher purposely erase middle rate to avoid central tendency. About the compensation and benefit, by the theory of Milkovich, researcher has developed own question about type of compensation and benefit employee can get in their company. To give richness in the research, we also provide descriptive question about gender, age, duration of work, level of job, and type of work.

Organisation brand questionnaire in this research consist four dimension including brand identification, brand commitment, brand loyalty, and brand performance. Employee engagement consist three dimension including physical engagement, cognitive engagement, and emotional engagement. Compensation questions are all about external compensation because it is physically form. Last, benefit questions including income protection, work life balance, allowances, paid time off, and services. To ensure that this questionnaire is valid and reliable to be used in the research, first of all we do pretest research. Validity and reliability coefficient result in this questionnaire are overall valid and reliable but in some items need to be revised. Researcher redefine the item to give new perceptions but still the same meaning. Some items which need to be revised resulting in a brand new questionnaire.

\section{RESULTS}

In the calculation of the effect of compensation, benefit, and organization brand to employee engagement using multiple regression method, determinant coefficient is 0.532 which means dependent variable employee engagement is $53.2 \%$ defined by independent variable compensation, benefit, and organization brand while the rest are another variable 
we don't say in this research. The significance amount is 0.000 for organisation brand, 0.030 for compensation, but 0.110 for benefit. It means that compensation and brand has significant effect on employee engagement but benefit is not.

Table 3. SPSS Result of Multiple Regression of Compensation, Benefit, and Organisation Brand to Employee Engagement

\begin{tabular}{|c|c|c|c|c|}
\hline Model & $R$ & R Square & B & Sig \\
\hline (Constant) & \multirow{4}{*}{0.729} & \multirow{4}{*}{0.532} & $-7.222 \mathrm{E}-17$ & 1.000 \\
\hline$O B$ & & & 0.706 & 0.000 \\
\hline EXCO & & & 0.212 & 0.030 \\
\hline $\mathrm{BE}$ & & & -0.155 & 0.110 \\
\hline
\end{tabular}

Another multiple regression of the effect from compensation and benefit to organisation brand resulting in determinant coefficients in 0.057 . Which means that $5.7 \%$ variable organisation brand defined by compensation and benefit. While the rest is defined by another variables we don't mention in this research. Significant coefficients of compensation to organisation brand is 0.235 and benefit to organisation brand is 0.542 . We can conclude thet neither compensation nor benefit has effect on organisation brand. The complet result shows on table below.

Table 4. SPSS Result of Multiple Regression of Compensation and Benefit to Employee Engagement

\begin{tabular}{|c|c|c|c|c|}
\hline Model & $R$ & R Square & B & Sig \\
\hline (Constant) & \multirow{3}{*}{0.239} & \multirow{3}{*}{0.057} & $1.248 \mathrm{E}-16$ & 1.000 \\
\hline EXCO & & & 0.162 & 0.235 \\
\hline$B E$ & & & 0.083 & 0.542 \\
\hline
\end{tabular}

Based on the results appears from the calculation using SPSS 16.0 above, we need to correlate those results with the hypotheses we proposed. Because the needs of this calculation is to answer the research questions in form of hypotheses. Results of the hypothesis is in the resume below.

Table 5. Hypotheses Result

\begin{tabular}{|c|c|c|c|l|}
\hline Hypothesis & Relationships & Sig & B & Conclusion \\
\hline $\mathrm{Hl}$ & Compensation has effect on organisation & 0.235 & 0.162 & Declined \\
\hline
\end{tabular}


Astri Utami Indriyani

Ignatius Heruwasto

\begin{tabular}{|c|c|c|c|c|}
\hline & brand & & & \\
\hline $\mathrm{H} 2$ & Benefit has effect on organisation brand & 0.542 & 0.083 & Declined \\
\hline $\mathrm{H} 3$ & $\begin{array}{l}\text { Compensation has effect on employee } \\
\text { engagement }\end{array}$ & 0.030 & 0.212 & Accepted \\
\hline $\mathrm{H} 4$ & Benefit has effect on employee engagement & 0.110 & -0.155 & Declined \\
\hline H5 & $\begin{array}{l}\text { Organization brand has effect on employee } \\
\text { engagement }\end{array}$ & 0.000 & 0.706 & Accepted \\
\hline
\end{tabular}

\section{DISCUSSION}

In this research there is a hope to enrich the research fields especially something correlated with startup business. Because in Indonesia, there are lack of research of this kind of theory. After creating a trial to 30 startup employees in Indonesia, researcher revised the questionnaire and then spread in for the real data collection. While data has been collected, first things researcher do is seeking for validity and reliability. To be seen in general, every variable in this research is having a coefficients above the standard. As well as realibility coefficients. So we can conclude that this questionnaire is valid and reliable.

If there are any invalid yet reliable item, this are BRPE1 and BRPE2. There are also invalid and unreliable items, BRCO1 and BRCO2. BRPE1 including a statement that said, "Tingkat kualitas jasa yang saya lakukan mencapai standar yang ditetapkan perusahaan ini." Item BRPE2 is about " "Terkadang, saya mengabaikan bagian pekerjaan yang seharusnya saya kerjakan." These items is invalid because the standards of job of every employee doesn't meet the standards company has set. So points given in this item is less than expected and unable the draw the real condition. For the second item, this is the item with reverse socring. So there could be different understanding between the respondents and what it should really mean. Next invalid and unrealiable item are BRCOI ("Komitmen saya untuk menjalankan brand ini meningkat seiring pengetahuan tentang brand.") and BRCO2 ("Saya sangat berkomitmen untuk menjalani janji brand kepada rekan."). It happened to be invalid and unreliable due to respondents who doesn't really understand about what is brand knowledge and brand promise.

This research found the effect from compensation to employee engagement and organsation brand to employee engagement. But there is no effect on compensation to organisation brand, benefit to organisation brand, and benefit to employee engagement. On the other side, organisation brand is stand also for a mediating variable. That is between compensation to employee engagement or from benefit to employee engagement. In the position where organisation brand is between compensation and employee engagement, compensation doesn't have effect on organisation brand but compensation has effect on employee engagement. So we can conclude that organisation brand is not a mediating variable in this realtionship. Then we see organisation brand in the realtionship between benefit and emmployee engagement. No effect on every variable in this relationship. That means organisation brand as well as the statement before, is not a mediating variable.

\section{CONCLUSION}


Eventough literature showed the effect on organisation brand (Anitha J, 2013), compensation and benefit as key factor of organisation brand (Blumenthal, 2011), and compensation and benefit as determinant of employee engagement (Abel, 2013). But those four variables, in term of startup company, is not fit enough to have a relationship as a whole. In this research, we successfully found that organisation brand have effect on employee engagement. But if we try to prove of compensation and benefit, only compensation have effect towards employee engagement. Whilst benefit have no effect at all to organisation brand or employee engagement. As we all know that compensation is a reward in monetary form. This kind of reward given to employee in an exact time employee can predict. So employee can feel secure about pay they got in a specific time. But it different with benefit. Benefit is a different way to give rewards to employee because it given in a non monetary form. And benefit was not given to employee as a routinity. As example, the benefit of eyeglasses is only for employee with certain time of work with different plafond depends on level. Another example is company's car. Not every employee have their own car. Only limited level and job can get this kind of facility. Due to this differences, it might affect why respondent give smaller scale on benefit.

The advantages we hope from this research are something startup business can do, such as:

1. Giving a suggestion to startup company in making a perfect simulation of compensation and benefit to every employee. In term of type and amount of compensation and benefit. Employee should feel the advantage of compensation and benefit from the company. Some suggestion we hope can be implemented in startup company including:

- Reward in form of product of its company

- Free lunch

- Simple sports facilities

- Free medical check up

- Gasoline allowances, household tools, car allowances, insurance, and any other

- Children school fee

2. Making a more accurate and specific strategy depends on company situation, about how implementing organisation brand to every system in company.

3. Increasing productivity. Productive employee will increase the amount of product and therefore increasing the revenue.

In subject of academic, this research can enrich the information of managerial about marketing and human capital. Because as we all know that every science is correlated and supporting each other.

If in the future others wants to make similar research, we have some suggestion due to limitation of this research. First, the proportion of respondents should be balance between back office and front office employee. Second, literature in supporting the basis of the research should be more added than present research. Third, as we see that compensation and benefit are not always affecting the dependent variables (organisation brand and employee engagement), then if we want to discuss more about startup company, we can consider another variables affecting those two. Such as clarity, commitment, communications, and culture. Maybe leadership, team and co-worker, training and career development, organizational policies, and workplace well-being can be considered too. 


\section{Astri Utami Indriyani \\ Ignatius Heruwasto}

In short, researchers always hope for the better research in field of human capital. Researchers who interested in startup business as well hopes for more research about this type of company. Because in Indonesia, startup company is one of a kind. Every advantages of the research is of course for a better Indonesia.

\section{REFERENCES}

Abel, M 2013. 'The social and financial benefits of developing employee satisfaction'. International Journal of Management \& Information Systems, Vol. 17, No. 2, pp. 83-88.

Abratt, R and Kleyn, N 2012. 'Corporate identity, corporate branding and corporate reputations', European Journal of Marketing, Vol. 46, No 7-8, pp. 1048-1063.

Ahmad, N., labal, N., Kanwal R., Javed. H, and Javed. K 2014. 'The mediating role of employee engagement in relationship of internal branding and brand experience: Case of service organizations of Dera Ghazi Khan'. International Journal of Information Business and Management, Vol. 6, No 4, pp. 26-41.

Anitha, J 2014. 'Determinants of employee engagement and their impact on employee performance'. International Journal of Productivity and Performance Management, Vol. 63, N. 3, pp. 308-323

Apa Itu Startup? Bagaimana Perkembangan Dunia Bisnis Startup di Indonesia? $(2016,921)$. Retrieved from Maxmanroe: https://www.maxmanroe.com/apa-itu-startup-bgmnperkembangan-dunia-bisnis-startup-di-indonesia.html

Blumenthal, D 2011 . Internal branding: does it improve employees' quality of life? Institute for Brand Leadership.

Boyd, $G$ and Sutherland, M 2006. 'Obtaining employee commitment to living the brand of the organization. Journal of Business Management, Vol. 37, No 1, pp. 209-216

Condos, JR 2016. The relationshop between transformational leadership and employee engagement in Southwest Lovisiana Law Firms. Dissertation, Northcentral University, Northcentral.

Mahatma, R. (2013, June 19). Apakah Definisi Startup Itu? Kenapa Sering Dikaitkan Dengan Teknologi Atau Internet? Retrieved from StartupBisnis: http://startupbisnis.com/apakah-definisi-startup-itu-kenapa-sering-dikaitkan-denganteknologi-atau-internet/

Martocchio, J. J. 2015. Strategic Compensation: A Human Resource Management Approach (7th ed). New Jersey: Pearson.

Milkovich, G., Newman, J., Gerhart, B. 2011. Compensation (1 $1^{\text {th }}$ ed). New York: McGraw-Hill Irwin.

Murphy, K. J.: 1999, 'Executive Compensation', in O. Ashenfelter and D. Card (eds.), Handbook of Labour Economics (Elsevier, Amsterdam), pp. 2485-2563.

Punjaisri, K., Wilson. A, and Evanschitzky. H 2009. 'Internal branding to influence employees' brand promise delivery: a case study in Thailand' Journal of Service Management, Vol. 20, No 5, pp. 561-579.

Punjaisri, K., Evanschitzky. H, and Wilson. A 2009. 'Internal branding: an enabler of employees' brand-supporting behaviours'. Journal of Service Management, Vol. 20, No. 2, pp. 209-226. 